Milel ve Nihal, 13 (2), 2016

\title{
Tanrılaştırma ve Şeytanlaştırma Arasında Mitolojik Bir Figür Olarak Asklepios
}

BilaI PATACI ${ }^{*}$

Asklepios as a Mythological Figure Between Deification and Demonization

Citation/@: Patacı, Bilal, (2016). Asklepios as a Mythological Figure Between Deification and Demonisation, Milel ve Nihal, 13 (2), 154-182.

Abstract: Greek mythology encloses whole of the sacred story that was told about the paganism as adopted in the Hellenic world. Although they formed the worldviews of human beings in ancient times as much as the Olympian gods did, figures described as heroes in the mythical narrative about these gods and their adventures have not been discussed adequately in academic works. One of these is definitely Asklepios. Sources spoke of him as a man but later he became a deity with the help of the cults and temples built in his name. As the cult was deeply embraced by the Greco-Roman world, with the Christian faith's spreading in the same region, it was demonized and gradually disappeared from the scene. This study presents a twofold reading on the basis of the historical facts. The first one will deal with the process of Asklepios's deification while the second one will enlighten the way towards his demonization.

Key Words: Asklepios, Asklepeion, Cult, Deification, Demonization

Atıf/C): Patacı, Bilal, (2016).Tanrılaştırma ve Şeytanlaştırma Arasında Mitolojik Bir Figür Olarak Asklepios, Milel ve Nihal, 13 (2), 154-182.

Öz: Yunan mitolojisi Helen coğrafyasında kabul gören paganizme ilişkin anlatılan kutsal hikâyenin bütününü teşkil eder. Olimpos tanrıları ve onların serüvenleri etrafında dönen bu mitik kurgu içerisinde kahramanlar olarak

* Arş. Gör., İstanbul Üniversitesi, İlahiyat Fakültesi, Dinler Tarihi Anabilim Dalı [bilalpataci@gmail.com] 
ifade edilen kategoride yer alan bazı figürler esasında eskiçağ insanının inanç dünyasını Olimpos tanrıları kadar şekillendirmekle birlikte akademik çalışmalarda yeteri kadar ele alınmamıştır. Bunlardan birisi de kuşkusuz Asklepios'tur. Kaynaklar ilk olarak ondan insan olarak bahsetmekteyken, adına tesis edilen kült ve tapınaklar aracılığıyla tanrılaştırılmıştır. GrekoRomen dünyanın en önemli kültlerinden biri olarak kabul gördüğü sırada, Hıristiyan inancının aynı coğrafyada yayılması neticesinde bu kez şeytanlaştırılmış ve buna bağlı olarak Asklepios kültü de zamanla ortadan kalkmıştır. Bu çalışmada bilinen tarihsel verilerin ışığında iki aşamalı bir değerlendirme öngörülmektedir. İlk aşamada Asklepios'un "tanrılaştırma" süreci, ikinci aşamada ise "şeytanlaştırma" süreci metinler aracılığıyla ortaya konulmaya çalışılacaktır.

Anahtar Kelimeler: Asklepios, asklepion, kült, tanrılaştırma, şeytanlaştırma

Nerede yaşadığını biliyorum; şeytanın tahtı oradadır." (Vahiy 2:13)

\section{Giriş}

Hıristiyan Kutsal Metinleri içerisindeki Vahiy kitabının yazarı Bergama'daki kilisenin meleğine hitaben yukarıdaki ifadeyi kullanır. Vahiy yazarı için Bergama, şeytanın tahtının bulunduğu yerdir. Her ne kadar Vahiy yazarının kim olduğunu tam olarak bilmesek de metindeki yedi kilisenin Greko-Romen dini ve kültürünü önemli ölçüde yansıtan Anadolu şehirlerinde olduğunu söyleyebiliriz. Bu yedi şehirden Bergama' da varlık gösteren kültleri bilmek, Vahiy yazarının kastını anlamamıza yardımcı olacaktır.

Öyle görünüyor ki Vahiy yazarı "şeytan” ifadesiyle İsa'dan önce yaşayan; onunla benzeri bir tanrısallığa haiz görülen birini kastetmekte ve İsa'nın muhtemel rakiplerini saf dişı etmek istemektedir. Bilebildiğimiz kadarıyla Vahiy kitabının yazıldığı dönemde Bergama'da Grek tanrılarından Zeus, Athena, Dionysos ve Asklepios'a ait kültlerin varlığı bilinmektedir. ${ }^{1}$ Asklepios haricindeki isimler Grek mitolojisinin başat figürleridir. Vahiy yazarı "şeytanın tahtı" ifadesiyle bunlardan birine atıfta bulunmuş olabilir. Kanaatimize göre bu isimlerden İsa' ya en çok benzeyen "şeytan" ifadesinin muhtemel muhatabı olmalıdır. Bu doğrultuda söz konusu tanrısal

\footnotetext{
1 Soi Agelidis, "Cult and Landscape at Pergamon", Sacred Landscapes in Anatoliaand Neighboring Regions, Ed. by. C. Gates, J. Morin, T. Zimmermann, British Archeological Report, Oxford:2009, s. 47.
} 
varlıklara ilişkin bilgiler incelendiğinde "şeytan" ifadesiyle Asklepios'un kastedilmiş olma olasıllı̆̆ yüksek görünmektedir. Özellikle Asklepios ile İsa biyografileri arasındaki benzerlik ve her iki ismin de "soter" (kurtarıc1) ve filantrop (insan sever/canlısı) lakaplariyla bilinmesi, Grek mitolojisinin pek adı duyulmamış bu figürünü konumuz açısından daha da önemli kılmaktadır. Üstelik Asklepios etrafında şekillenen kültün sembolü olan yılan figürünün HıristiyanYahudi geleneğinde şeytan ile özdeşleştirilmesi bu kanaati daha da güçlü kılmaktadır. Üstelik kimi Hıristiyan yazarların - Tertullianus, Eusebios, Lactantius - metinlerinde görülen Asklepios'un kötücül imajı da Vahiy yazarının ifadesiyle devamlılık arz etmektedir. Oysa Hıristiyanlığın ilk üç yüzyılı da dahil olmak üzere neredeyse bir milenyum süresince Asklepios Greko-Romen tanrıları arasında zikredilmiş, hatta bazı Yunan ve Roma şehirlerinde Olimpos tanrılarından daha fazla ilgi görmüştür. Uzun bir süredir devam eden şöhretinin nasıl sona erdiği merak konusudur. Yine bu şöhretin onda nasıl belirdiği de ayrıca dikkatleri çekmektedir. Bu sebeple tarihsel verileri kronolojik bir sira ile değerlendirerek Asklepios'un kimliğini ve etrafında şekillenen kültü tanımak mümkündür. $\mathrm{O}$ halde Asklepios kimdir?

Asklepios Yunan Mitolojisinde tıbbın ve şifanın tanrısı olarak bilinir. Hakkında bilgi veren bilinen ilk kaynak Homeros'un ${ }^{3}$ Ilyada isimli eseridir. İlyada' da Podallarius ve Machaon isimli iki hekimin babası olarak bahsedilen Asklepios'un Teselya'dan gelen kusursuz bir hekim olduğuna ilişkin ifadeler yer alır. "Kusursuz hekim" ifadesi henüz MÖ. VIII. yüzyılda Asklepios'un şifacı kimliğinin bilindiğini gösterir. Homeros'tan sonrasında Asklepios hakkında mitolojik anlatılar belirmeye başlar. Grek mitolojisinin en önemli yazarlarından Hesiodos5, Asklepios'un ailesine ilişkin birbirinden

\footnotetext{
2 Michael B. Cosmopoulos, Greek Mysteries, Routledge, New York:2005, s. 176.

${ }^{3}$ Homeros' un ne zaman yaşadığına ilişkin farklı kayıtlar söz konusudur. Günümüz araştırmacıları daha çok MÖ. IX. ve VIII. yüzyıllar üzerinde durur. Üstelik Homeros'un tek bir ozan olmadığı o yüzyıllar içersinde birden fazla ozana ait şiirlerin Homeros ismine atfen derlendiği düşünülür. Homeros' un eserleri sözlü olarak MÖ. VIII. yüzyılda derlenmiş, yazıya ise çok daha sonra geçirilmiştir.

${ }^{4}$ Homer, Iliad, Trans by. A.T. Murray, Harvard University Press, Londra:2001, ss. $179,531$.

${ }^{5}$ Hesiodos' un yaşadaoğı tarih olarak kaynaklar MÖ. 750-650 yılları arasına işaret eder.
} 
farklı iki kayıt sunar. Bunlardan birisinde Asklepios'un annesi olarak Messenialı Arsinoi ismi yer alırken, diğerinde ise Teselyalı Coronis ismi kaydedilmiştir. ${ }^{6}$ Her iki kayıtta da baba olarak Apollon zikredilir. Muhtemelen anne isimlerindeki bu farklılık Asklepios'un şöhretinden sonra Yunan şehirlerinin onunla anılmak istemesinden kaynaklanmış olmalıdır. Ama daha önemlisi her iki anlatı Asklepios ile Apollon arasında bir bağ tesis edilerek tanrılaşma aşamasını önemli bir işlev görmüştür.

Homeros şiirleri ile aynı ölçüyü kullandığı için Homerik İlahiler olarak bilinen külliyatta ise Asklepios adına bir övgü bölümü vardır. Homeros'un "kusursuz hekimi" burada da tanrı Apollon'un oğlu ve şifacı olarak betimlenir.7

Mezkûr üç kaynağın Asklepios hakkında yeterli bir bilgi sunmadığı ortadadır. Oysa MÖ. V. yüzyıl şairlerinden Pindarus'un anlatısı Asklepios hakkında oldukça geniş bir hikâyeye yer verir. Epinikia isimli eserinde ilk göze çarpan bilgi onun bir kahraman olduğuna; insanları hastalık ve türevlerinden koruduğuna ilişkindir. Metinde Asklepios'un doğumu anlatılır. Buna göre Asklepios ölümlü bir kadın olan Coronis ile Zeus'un oğlu Tanrı Apollon'un çocuğudur. Coronis, Asklepios'a hamile iken Arcadia'dan gelen Iscyhs isimli bir yabancı ile birlikte olur. Bu durumu bir alakarga tarafından öğrenen Apollon ise kardeşi Artemis'i Coronis'i cezalandırması için gönderir. ${ }^{8}$ Artemis' in emri doğrultusunda Hephaisteos büyük bir ateş yakar ve Coronis'i odunların üzerine bağlar. Alevler içindeki Coronis' in yanışını seyreden Apollon o esnada ruhunda bir acı hisseder ve Coronis' in karnından oğlu Asklepios'u çekip alır. ${ }^{9}$

Pindarus'un hikâyesinden farklı olarak Epidariusluların Asklepios'un doğumuna ilişkin başka bir anlatısı mevcuttur. Buna göre Phlegyas kentinin kurucusu olan Phlegyas'ın Coronis isimli bir kızı

\footnotetext{
${ }^{6}$ Edelstein, Emma J., Edelstein, Ludwig, Asclepius: Collection and Interpretation of the Testimonies, John Hopkins University Press, Londra: 1998, ss. 21-26

${ }^{7}$ Hesiod, Homeric Hymns and Homerica, Ed. By. G. P. Gooldi Tr. Hugh G. Evelyn White, Harvard University Press, London:1982, s. 441s

${ }^{8}$ Efsaneye göre Apollon'a haber veren alakarga Apollon tarafından lanetlenir. Bu yüzden rengi siyaha döner. Walter A. Jayne, The Healing Gods of Ancient Civilizations, University Books, New York: 1962, s. 245.

9 Pindarus, Pythian Ode III:5-65, (Pindar, Olympian Odes, Pythian Odes, Ed. and Trans. William H. Race, Harvard University Press, Londra:1997).
} 
vardır. Coronis Apollon'dan hamile kalmıştır. Bebeği Asklepios'u gizlice Titthion dağında doğurur ve terk eder. Bu sırada dağda kaybolan keçisini ve köpeğini arayan çoban Arasthanas, Asklepios'un keçiyi emdiğini ve vücudundan beyaz bir 1şık çıktığını görür ki bu alamet sonradan onun tanrısal bir doğaya sahip olduğuna yorumlanır. ${ }^{10} \mathrm{Bu}$ versiyondan farklı olarak mitosun Epidarius'taki içeriğinde anne Coronis'in bebeği -daha sonra Asklepios tapınağının inşa edildiği - dağda kendi başına doğurması ve doğuma ilişkin kayıtta Apollon'dan bahsedilmemesi, şehirdeki Apollon tapımının etkisini yitirdiğini göstermektedir. ${ }^{11} \mathrm{Bu}$ detay bir yana, her iki anlatı ile Asklepios'un biri insani diğeri tanrısal kökenine ilişkin ayrı perspektifler ortaya konmaktadir.

İki ayrı kayıtla birlikte Asklepios'un tababet ilmini öğrenmesine ilişkin ortak bir anlatı mevcuttur. Buna göre Apollon onu, tababeti öğretmesi için Magnezyalı kentauros/sentor ${ }^{12}$ Kheiron'a teslim eder. Kheiron'un çırağı olarak yetişen Asklepios'un iyileştirdiği hastalar sebebiyle ünü kısa sürede yayılır. Hatta ölüleri dahi dirilttiği ifade edilir ki, ${ }^{13}$ Hades bu eylemi kendi yetki alanına müdahale olarak görür ve Asklepios'u Zeus'a şikâyet eder. ${ }^{14}$ Pindarus'un şiirine göre Asklepios ölüleri diriltmesinin bir cezası olarak Zeus tarafından gönderilen yıldırım sonucunda ölür. ${ }^{15}$ Esasında bu anlatı

${ }^{10}$ Jayne, The Healing Gods of Ancient Civilizations, s. 245; Robert Graves, The Greek Myths I, The Folio Society, London: 1998, s. 168. Asklepios'un tam olarak nerede doğduğu belirsizdir. Kaynaklarda, Epidarius haricinde Trikka, Messenia, Sicyon isimleri de geçmektedir.

${ }^{11}$ Olympia Panagiotidoi, "Asclepius' Myths and Healing Narratives: CounterIntuitive Concepts and Cultural Expectations ", Open Library of Humanities, c. 2, s. 1, 2016, s. 6. (DOI: http://dx.doi.org/10.16995/olh.34).

${ }^{12}$ Kentauros/sentor, Grek mitolojisinde yarı at yarı insan görünümlü varlıklardır. Genellikle vahşi karakterli varlıklar olarak bilinirler. Ancak Kheiron ve Pholos isimli iki sentor türlerinin diğer örneklerinin aksine oldukça insansever ve hayırsever varlıklar olarak nitelendirilir. Bkz. Pierre Grimal, Mitoloji Sözlüğ̈̈: Yunan ve Roma, Kabalc1, İstanbul:2012, s. 361.

${ }_{13}$ Ölümden dirilttiği kimseler arasında Lycurgus, Capaneus ve Tyndareus isimleri zikredilir. Bkz. Graves, The Greek Myths I, s. 169.

14 Philip Matyszak, The Greek and Roman Myth, Thames and Hudson, London:2010, s. 116; Gerald Hart, "Asclepius: God of Medicine" Canadian Medical Association Journal, 1965: V. 92, s. 233.

${ }^{15}$ Pindarus, Pythian Ode III:5-65; Graves, The Greek Myths I, s. 169. 
Asklepios'un ölümünden çok ölümsüzleştirilmesinin hikâye edilmesidir. Nitekim kayıtlara göre ölümünün akabinde yeniden dirilmiş ve Zeus tarafından kendisine tanrılık payesi verilmiştir. ${ }^{16}$ Mitosun Apollodorus'taki (ö. MÖ. 120) kaydına göre ise Asklepios Zeus tarafından diriltilmiştir. ${ }^{17}$ Ölümden dirilmesi, ölülerin ebedi ikametgâhı olan Tartarus'tan bir yılan kılığında kurtulmasıyla gerçekleşir. ${ }^{18}$ Ancak tanrısal bir doğaya kavuştuğunda bir daha ölüleri diriltemez. ${ }^{19}$

Görüldügüü üzere Asklepios hakkında en eniş anlatıya yer veren isim Pindaros'tur. Onun bu geniş anlatısı, yaşadığı tarihi göz önünde bulundurduğumuzda ayrıca ehemmiyet kazanmaktadır. Çünkü bu tarih aynı zamanda Asklepios kültünün ilk ortaya çıktığı zaman diliminin hemen sonrasına denk gelmektedir. Bu tarih öncesinde Homeros ve Hesiodos' un anlattıklarını da bir anlamda tasdik eden şair, anlatısı ile kültün kalıcı olmasına ve Yunan dünyasına yayılmasına büyük katkı sağlamış olmalıdır.

Asklepios anlatılarının haricinde ondan bahseden pek çok kaynak bulmak mümkündür. MÖ. VII. yüzyıldan MS. VI. yüzyıl arasındaki Yunan şiirinin bir koleksiyonu olan Anthologia Palatina'da Platon'a ilişkin bir şiirde Asklepios'a yer verilmekte ve Platon ve Asklepios'un sahip oldukları yetenekleri Apollon'dan aldıkları vurgulanmaktadır:

Eğer Apollon Platon'a vermemiş olsayd1 Yunanistan'1 Yazılarıyla nasıl iyileştirecekti insanların ruhlarını Apollon oğlu Asklepios, iyileştirirken insanların bedenlerini Platon iyileştirir ölümsüz ruhları. ${ }^{20}$

Benzeri bir ifade başka bir Yunan şiirinde şöyle dile getirilir:

Apollon'un iki oğlu vardı:

Asklepios ve Platon

Biri bedenleri,

diğeri ise ruhları kurtard1. ${ }^{21}$

\footnotetext{
16 Hart, "Asclepius", s. 233.

17 Apollodorus, The Library II, Harvard Univeristy Press, New York, s. 19.

18 Matyszak, The Greek and Roman Myth, s. 116.

${ }^{19}$ Edelstein \& Edelstein, Asclepius, s. 56.

20 Ancient Greek Lyrics, Trans. Willis Barnstone, Indiana University Press, Indianapolis:2010, s. 159.

21 Ancient Greek Lyrics, s. 242.
} 
Yukarıdaki şiirlerde vurgu Platon üzerindedir. Ancak Asklepios'un Yunan felsefesinin önemli simalarından Platon'la karşılaştırılması dahi onun Antik Yunan medeniyetinde son derece önemli olduğunu göstermektedir. Ayrıca her iki ismin Apollon'dan ilham aldıklarının belirtilmesi de Asklepios'a ilişkin daha önceki anlatıları desteklemektedir. Bununla birlikte bu şiirler metafizik varlıkların fizik dünyadaki gelişmelerin de kaynağı olduğu vurgusunu öne ç1karmaktadır. Gerek felsefe gerekse tıp gibi iki önemli disiplinin kaynağı olarak tanrı Apollon'un gösterilmesi Yunan tarih yazımı ve mitoloji ilişkisi hakkında önemli ipuçları sunar.

Hesiodos ve Pindarus'un Asklepios'un doğumuna ilişkin anlatımlarının bir benzerini şair Ovidius (ö. MS. 17) de nakletmektedir. Ovidius, diğer metinlerden farklı olarak Sentor Kheiron'un kızı Ocryhoe'nin Asklepios hakkındaki kehanetine yer verir. Kehanete göre Asklepios tababet ilmine vakıf olacak, dünyanın şifacısı olarak tanınacak, tanrısallaşacak, ölecek ve tanrılığı devam edecek. ${ }^{22}$

Asklepios'tan bahseden bir diğer kaynak ise Marcus Aurelius Antoninus'a (ö. MS. 180) ait Meditationes isimli eserdir. Yazar tıpk1 Homeros gibi Asklepios'un hekimliğine işaret etmekte ve bir takım hastalıklarla kendisine gelenlere sunduğu reçetelerden bahsetmektedir. ${ }^{23}$ Bu kaynaklarm haricinde Celsus (ö. MS. II. yy), Asklepios'tan tıbbın kurucusu olarak bahsetmekte; Antik Roma'nın en önemli hekimlerinden Galenos (ö. MS. 210) ise hayatı boyunca Asklepios'un hizmetinde olacağını söylemektedir. Ayrıca Platon (ö. MÖ. 348), Epictetus (ö. MS. 135), İmparator Julianus (ö. MS. 360), gibi yazarlarla birlikte Hiristiyan yazarlar Tertullianus (ö. MS. 220), Justin Martyr (ö. MS. 265), Origenes (ö. MS. 254), ve Eusebios (ö. MS. 339)' da Asklepios'a ilişkin bilgiler aktarmaktadır. ${ }^{24}$

\section{Asklepios'un Tanrılaştırılması}

Homeros sonrası kaynakların ekseriyetinde Asklepios tıbbın tanrısı olarak kaydedilmiştir. Bu tanrılık payesi literal olarak yorumlanmaz ise bu ifade ile Asklepios'un tababetin antik Yunan'daki en önemli

\footnotetext{
22 Ovid, The Metamorphoses II, Trans. Horace Gregory, The Viking Press, New York:1958, s. 73-75; Graves, The Greek Myths I, s. 169.

23 Marcus Aurelius Meditations, Trans. M. Hammond, Penguin Books, Londra:2006, s. 37.

${ }^{24}$ Edelstein \& Edelstein, Asclepius, s. 370-373.
}

160 
temsilcisi ve kurucusu olarak değerlendirilmesi mümkündür. Nitekim tanrı ya da ilah ifadesi bu kasitla günümüzde dahi kullanılmaktadır. Ancak Asklepios anlatıları, tanrılık payesinin sadece tababetteki maharetinden mülhem bir niteleme olmadığını, aksine Asklepios'a ait tapinakların oluştuğunu ve Yunan anakarasında yaygın bir kültün varlığından bahseder. Dolayısıyla dini ve mitolojik çemberin, günümüzde seküler olarak belirlenen bütün alanları kuşattığı bir zaman diliminde Asklepios' un tanrılardan bir tanrı olarak kabul gördüğü gerçeği ortaya çıkmaktadır. Ancak bu kabulün ilk belirdiği zamanı tespit etmek için mezkûr metinlere yeniden bir göz atmak gerekecektir.

Daha önce de ifade edildiği üzere Asklepios hakkında bilgi veren en erken kaynağın - Homeros'un İlyada adlı eseri - ondan "tanrısal bir figür" yerine "kusursuz bir hekim" olarak bahsetmesi ilginçtir. Bu nedenle bir "anthropos" olan Asklepios'un muhtemelen Homeros sonrasındaki metinler aracılı̆̆ıyla insan doğasından tanrısallığa ulaştıııldığını düşünebiliriz. Nitekim pek çok kaynak Asklepios'un tanrılaştırıldığına atıfta bulunmaktadır. ${ }^{25}$ Tanrılaştırmanın ne zaman ve nasıl gerçekleşmiş olabileceğini ise metinler vasitasıyla çözmeye çalışmak gerekecektir.

Homeros'un aktardığına göre Asklepios, Teselyalı kusursuz bir hekimdir. Aynı kaynakta Podallarius ve Machaon isimli hekimlerin de babası olduğu söylenir. Podallarius ve Machaon ise Truva savaşında yer alan hekimlerdir. Dolayısıyla bu verilerden hareketle Asklepios'un hekim olarak tanındığg tarihe ilişkin tahminde bulunmak mümkündür. Bilindiği gibi Truva savaşının tarihi en erken MÖ. XII. yüzyıl olarak zikredilir. Bu bilgiyi esas alacak olursak Asklepios'un bu tarih öncesinde yaşadığı düşünülebilir. Bu veriden hareketle en azından MÖ. XII. yüzyıl öncesinde bir hekim olarak

${ }^{25}$ Cicero, De Legibus, II, 8,19, De Natura Deorum, III, 18, 45 ; Porhyrius, Epistula ad Marcellam, 7; Origenes, In Jeremiam Homilia, V, 3, Contra Celcum, III, 22; Xenophon, Cynegeticus, I, 6; Celsus, De Medicina,Proomium, 2; Galenus, Proprepricus, 9,22; Athenagoras, Pro Christianis, 30,1-2; Georgius, Hamartalus, Chronicon,I,54; Augustinus, De Civitate Dei, IV, 27; Lactantius, Divinae Institutiones, I, 19, 3-4; Apuleis, De Deo Socratis, XV, 153; Pausanias, Descriptio Graeciae, II, 26, 10; Eustathius, Commeentarii ad Homeri Illiadem, XI, 517-518 (Kaynakların hem orjinal metinleri ve hem de İngilizce tercümeleri için Bkz. Edelstein-Edelstein, Asclepius: Collection... isimli eserin içindedir). 
bilinen Asklepios'un Homeros'un çağına dek herhangi bir tanrısallaştırmaya tabi tutulmadığı sonucuna ulaşılabilir. Homeros'un en geç VIII. yüzyılda yaşadığı düşünülürse, tanrısallaştırmanın da bu tarih sonrasında vuku bulması gerekir ki, bu da bizi özellikle Pindarus ve Hesiodos'un metinlerine sevk eder.

Daha önce Pindarus ve Hesiodos'un birbirine yakın olarak Asklepios hakkındaki kayıtlarına yer verilmişti. Bu nedenle kayıtların muhteviyatını yinelemeye gerek yoktur. Ancak mezkûr bilgiler içerisinden Asklepios'un kutsal yolculuğuna ilişkin ipuçlarını tekrar zikretmekte yarar vardır. Bu ipuçları eşliğinde tanrısallaştırmaya dair "neden" ve "nasıl" sorularının yanıtlarını bulmak mümkündür.

Yunan mitolojisi sadece antropomorfik tanrıların değil, titanlar, kahramanlar ve yarı insan yarı hayvan türünde varlıkların da hikâyelerini aktarır. Tanrısal varlıklar arasındaki hiyerarşi Olimpos tanrıları sabit olmak kaydıyla değişiklik arz edebilir. Yani bir tanrısal figür hiyerarşik olarak kendisinden daha üstün bir tanrı tarafından cezalandırılabilir veya mertebesi yüceltilebilir. Ateşi Olimpos'tan alıp insanlığa sunan titan Prometheus'un Zeus tarafından cezalandırılması ya da Perseus'un kahramanlıklarından ötürü tanrılar katına çıkmaya hak kazanması panteondaki işleyişi izah etmek açısından güzel örneklerdir. Yani sıradan bir insan ya da yarı tanrısal bir figür Olimpos tanrılarının arasına katılmaya hak kazanacağı gibi tanrısal doğaya haiz bazı varlıklar da cezalandırılabilmektedir. Yunan tanrlar panteonundaki bu belirsizlik ve değişkenliğin sebepleri aynı zamanda Asklepios'un tanrılaştırılmasını imkan sağlamış olmalıdır. Bilindiği gibi Yunan tarihinde iz bırakan simaların insanlar nezdindeki konumlarından ötürü tanrılar panteonu ile aralarında kurulan biyolojik bir bağ üzerinden tanrılaştırılmaktadır. Muhtemelen Asklepios da özellikle iyileştirme sanatındaki şöhreti ve yeteneğini insanlığın hizmetine sunmasından ötürü tanrılık payesine erişmiştir. ${ }^{26}$ Esasında bu durum kültürün kökeni ve ilk örneklerine ilişkin Yunan tarih yazımıyla doğrudan alakalıdır.

26 Theodoratus, Graecarum Affectionum Curatio, III, s. 24-28; Arnobius, Adversus Nationes, VI, s. 44 (Edelstein-Edelstein, Asclepius: Collection... içinde, s. 109). 
Kültür Mitleri kitabında W. F. McCants kültürel başlangıçlara (protografi) ilişkin Yunan, Yahudi, Yakındoğu ve İslam tarih yazımlarını inceler ve bu tarih yazımlarından İslam ile Yakındoğu, Yunan ile Yahudi tarih yazımları arasında bazı paralellikler keşfeder. McCants'a göre kültür mitlerinin Yakındoğu versiyonunda tanrılar, kültürü oluşturan varlıklardır ve bu durum insanlığın faydasınadır. Benzeri bir yaklaşımı Yunan mitlerinde de görmek mümkündür. Ancak Yunan mitleri açısından sadece tanrının bahşettiği veya bizzat oluşturduğu kültür insanın yararına iken tanrılar tarafından yaratılmadıkça kültür ancak yıkım getirir. ${ }^{27}$ Prometheus'un Zeus'un insanlardan sakladığı ateşi çalıp insanlığa vermesi, Pandora'nın kutusundaki belaların serbest kalmasına neden olmuştur. Dolayısıyla ateş aracılığıyla yaratılan kültür tanrıların gazabını getirmiştir. Fakat tababet açısından durum farklıdır. Çünkü Asklepios öncesinde de Olimpos tanrılarından Apollon şifanın kaynağı olarak görülmektedir. Öte yandan da bir insan olarak Asklepios şifa ile irtibatlandırılır. Bu durumda Asklepios tababetin tanrısal kökeni ile insanlık arasında bir aracı konumundadır. $O$ tababeti insanlığa öğreten ve aktarılmasını sağlayan kimsedir. Bu aracılığı zamanla etrafında oluşan kült ile daha da önem kazanmış ve hakkındaki efsanevi hikayeler vasıtasıyla da tanrılaştırma gerçekleştirilmiştir. Bu sürecinin nasıl gerçekleştiği meselesi ise mitolojik metinlerden hareketle, (i) Asklepios'un tanrısal akrabalığı, (ii) mucizevi doğumu, (iii) ölüleri diriltmesi, (iv) ölümden dirilmesi ve (v) onunla ilişkilendirilen sembollerin tahlilleri üzerinden ortaya konulabilir.

Bilindiği kadarıyla Homeros'ta ve öncesi sözlü gelenekte Asklepios ve Apollon arasındaki tanrısal bağa işaret eden bir kayıt yoktur. Onun tanrısal bir soydan geldiğini ilişkin ilk kayıt Hesiodos ve Pindarus metinleridir. Bu metinler Asklepios ile Apollon arasında bir akrabalık bağı tesis eder. ${ }^{28}$ Tam da burada neden Asklepios ile diğer Olimpos tanrıları arasında değil de Apollon arasında bir bağ kurulduğu sorusu anlam kazanmaktadır. Bu soruyu yanıtlamak için Apollon'un yetki sahasını bilmek yeterli olacaktır.

${ }_{27}$ William F. McCants, Kültür Mitleri, Çev. Merve Tabur, İthaki, İstanbul: 2012, ss. 15,33 .

${ }^{28}$ Hyginius, Fabulae, CCLI, s. 2. 
Olimpos tanrılarının yetki dağılımına göre Apollon müzik, sanat, güneş ve şiirin tanrısıdır. Buna ilaveten kehanet yeteneğine sahiptir ve bu yeteneğini başkalarına aktarabilmektedir. Apollon, genelde bir ok ve yay ile bazen de lir ile resmedilir. Lirinden çıkan müziğin büyüleyici bir etkisi vardır. Okları da hem iyileștirme hem de hasta etme etkisine sahiptir. Bu nedenle Apollon iyileştirme sanatının esas kaynağı olarak kabul görür. ${ }^{29}$ Nitekim Apollon'un bu yetilerini Asklepios kültünde izlemek mümkündür. Asklepios kültünün tapım merkezleri olan asklepionlarda müzik ile tedavinin yapılması, Asklepios'un hastaların rüyalarına girip talimatlarda bulunarak onları iyileştirmesi şeklindeki uygulamalar neden Asklepios ile Apollon arasında bir bağ kurulduğu sorusunu yanıtlamaktadır. O halde bir kuvve olarak tanrilık mitolojik metinler aracılı̆̆ıyla Asklepios'a verimiştir. Bu kuvvenin fill kazanması ise Asklepios kültünün ortaya çıkması ve yayılması ile gerçekleşmiştir.

Tanrısal köken mitosuyla birlikte Asklepios hikâyesinde en dikkat çeken noktalardan birisi de onun insani kökenine yapılan vurgudur ki bu da onun doğum hikâyesinde belirmektedir. Ancak bu doğum sıradan bir doğum olmaktan uzaktır. Anne Coronis ateşler üzerinde can verirken Apollon, Coronis'in karnindan Asklepios'u çeker alır. Asklepios ölü bir bedenden canlı olarak çıkmıştır. Asklepios'un doğum sahnesi akıllara "sezaryen" doğumu getirir. İlk defa MÖ. VIII. yüzyılda uygulandığı düşünülen bu yöntem ${ }^{30}$, yine aynı yüzyıllarda Asklepios'un tanrılaştırılması için kullanılmış olmalidir.

Pek çok mitolojik anlatıda olduğu gibi tanrısal figürlerin - Horus, Attis, Krishna, Dionysus, Mithra, İsa - mucizevi doğumları onların tanrılaştırılmalarının önemli bir aşaması olarak karşımıza çıkar. Buna göre Asklepios da tıpkı diğer tanrısal figürler gibi mucizevi bir doğum ile - üstelik tababet açısından yeni bir teknik aracılığıyla - var olmuştur. Böylece bir yandan onun sıradan bir insan

\footnotetext{
${ }_{29}$ Graves, The Greek Myths, s. 61, 79-85; Philip Matyszak, The Greek and Roman Myths, Thames \& Hudson, New York: 2010, s. 82-86.

30 Samuel Lurie, Marek Glazerman "The History of Ceserean Technique", American Journal of Obstetrics and Gynecology, 2004, c.189, v. 6 s. 1803. Her ne kadar baz1 metinlerde sezeryanın tarihi MÖ. XVIII. yy'a kadar götürülse de Yunan mitolojisinin varlık gösterdiği topraklarda sezeryana ilk olarak Lex Regia isimli hukuki metinde atıf yapilır.
} 
olmadığı, tanrısal bir güce haiz olduğu ima edilirken; diğer yandan da insan bir anneden doğmasıyla Olimpos tanrılarının aksine insan sever bir karaktere sahip olması açıklanır.

Tanrısallaştırmaya yardımcı olacak diğer bir kurgu ise Asklepios'un bütün hastalıkları iyileştirdiği bilgisinin yanında ölüleri dirilttiğine inanılmasıdır. ${ }^{31} \mathrm{Bu}$ iddianın gerçeklikle ilişkisi burada tartışılmayacaktır. Bize göre önemli olan bu iddianın doğruluğundan ziyade bu iddia etrafında bir inancın teşekkül etmesidir. Çünkü Asklepionlarda tedavi edilen hastalıklar ölümcül olmadığı arkeolojik veriler aracılığıyla bilinmektedir. Dolayısıyla ölüleri diriltmesi onun şöhreti ve mahareti ile ilgili olmalıdır.

Her ne kadar insanoğlu ölümlü bir canlı olduğunun bilincinde olsa da ölümsüzlük arayışından da vazgeçmemiştir. Pek çok gelenek ölümsüzlüğü arayan karakterlere yer vermiştir. Hatta kimi geleneklerde ölümsüzlüğün bir iksiri ya da formülü olduğu düşünülmüş, hatta bu iksir bulunmuş ancak bir şekilde ortadan kaybolmuştur. $\mathrm{Bu}$ anlatı bir taraftan insan doğasının ölümlüğünü nihai olarak vurgularken öte taraftan da ölümsüzlük özlemini yansttmaktadır. Nitekim İslam geleneğinde Lokman Hekim/Hâkim olarak bilinen ve tababetin atası olarak da kabul gören bilgenin de ölümsüzlük iksirini aradığı, hatta bulduğu ve kaybettiği nakledilir. ${ }^{32}$

Anlaşıldığı kadarıyla tababetin kökeniyle irtibatlı görülen kimseler hemen hemen bütün toplumlarda benzeri bir biyografiye sahip olmuştur. Aynı şekilde ölüm de çaresi mümkün bir hastalık olarak düşünülmüş ve bu sebeple şifa ilminde mahir kimselerce bu çarenin bulunduğuna ilişkin bir inanç da teşekkül etmiştir. Asklepios'a ilişkin anlatılanlar da bu inancı yansıtmaktadır. Öte taraftan ölüleri diriltmesi her ne kadar Asklepios'un oldukça mahir bir hekim olduğuna yorulsa da, Olimpos düzenini de sarsmaktadır. Ölüleri diriltmek öncelikle ölülerden ve yer altından sorumlu tanrı Hades'in yetki sahasına müdahale olarak algılanır. Üstelik bu durumdan Hades gibi Zeus da rahatsızdır. Bu sebeple Asklepios, Zeus

${ }^{31}$ Asklepios'un dirilttiği kimseler arasında Kapaneus, Tyndarens, Hippolytos, Glaukos zikredilir. Jayne, The Healing Gods of Ancient Civilizations, s. 251.

32 Ömer Faruk Harman, "Lokman", Diyanet İslam Ansiklopedisi, TDV, Ankara:2003, c. 23, s. 205; Ahmet Gül, “Lokman Hekim ve Öğütleri”, Erciyes Üniversitesi İlahiyat Fakültesi Dergisi, S. 2, Kayseri:1985, s. 390. 
tarafından öldürtülür. Bu ölüm Asklepios için bir son değil yeni bir başlangıcın ilk adımıdır. Ölü bir bedenden canlı olarak doğan Asklepios'un ikinci ölüm tecrübesi de uzun sürmeyecektir. Böylece daha çok "kitonik" yani yeraltı dünyasına ait bir karakter iken Zeus'un yıldırımı sonucunda "göksel/celestial" bir makam ile ödüllendirilecektir. ${ }^{33}$ Tanrı veya tanrısallıkla irtibata geçmenin, yeraltının labirentlerinde yok olmaksızın/yüzleşmeksizin gerçekleşmeyeceğini öğreten bu anlatı sadece Asklepios kültünde değil, İnanna, Perseus, Demeter kültlerinde de karşımıza çıkmaktadır. Ancak İsa'nın ölümden diriliş tecrübesi ile karşılaştırılınca her iki figürün kutsal yolculuğunun çok daha benzer olduğu görülecektir. Bilindiği gibi İsa Hıristiyan itikadına göre tıpkı Asklepios gibi ilahi inayetin tarihe müdahil olmasıyla çarmıhta kendisini feda etmiş ve sonradan dirilmiştir. Ölümüyle dirilmesi arasındaki üç günlük süre zarfında Hades'e gitmiş ve yeraltından muzaffer bir şekilde çıkarak Tanrı'nın sağ yanına yükselmiştir. ${ }^{34}$ Nitekim bu bariz benzerlik M.S. IV. yüzyılda iki kurtarıcı figürün karşılaştırılmasına ve politik güce sahip Hıristiyanlarca Asklepios kültünün sonlandırılmasına neden olacaktır.

Asklepios'un tanrısallaştırması ile ilgili son olarak Asklepios freskleri, resimleri ve heykellerinde sıklıkla görülen semboller üzerinde durulmalıdır. Hemen hemen bütün görsellerde dikkati çeken ayrıntı, Asklepios'un sembolü olarak kabul edilen yılanlı bir asa ile resmedilmesidir. ${ }^{35}$ Bazı görsellerde ise oturarak resmedilen Asklepios'un asası olmamasına rağmen aynı görsel içinde yılan figürüne yer verilmektedir. Bilindiği gibi mitolojide pek çok karakterin y1lanlı asalar tuttuğu görülür. Asa ile ilgili değerlendirmeler - konumuzun dışında olduğu için- bir kenara bırakılıp yılan figürüne odaklanılırsa, hemen hemen bütün mitolojilerde yılan figürünün rastlanacaktır. Tekvin'de, - Âdem'in ilk günahının anlatıldığı hikâyede - şeytan yılan kılığında insanoğlunu kandırır. Bu hikâyeyi asli günah doktrinine referans kabul eden Hıristiyan yorum ${ }^{36}$, yılanı

\footnotetext{
${ }^{33}$ Jayne, The Healing Gods of Ancient Civilizations, s. 303.

${ }^{34}$ Elçilerin İşleri, 2:31-33

${ }^{35}$ Jayne, The Healing Gods of Ancient Civilizations, s. 242.

36 İlk günah hikayesi Yahudi gelenekten farklı olarak en erken Pavlus tarafından yorumlanmıştır. Pavlus, Romalılara Mektubu'nda günahın ölüme sebebiyet verdiğini ifade etmiştir (Rom. 5:12). Sonraları Bu Pavlusçu yorumu sürdüren kilise
} 
düşüşün önemli aktörleri arasında görerek onu şeytanlaştırmıştır. Ancak Hıristiyanlık öncesi anlatılarda yılan, bilgeliği, yaşamın özünü, ölümsüzlüğü ve gücü temsil etmektedir. ${ }^{37}$ Muhtemelen bu demonizasyonun nedeni Hıristiyanlığın kendisinden önceki tarihe bütünüyle cephe almasıdır. Çünkü yılan Hıristiyan öncesinde, kabul edilen mitik anlatılarda olumlu bir imaja sahiptir. Konu dışına çıkmamak için yılanın diğer mitik figürlerle olan ilişkisine girilmeyecektir. Bunun yerine tababetin tanrısı Asklepios ile yılanın neden sürekli birlikte resmedildiği sorusu yanıtlanmaya çalışılacaktır.

Asklepios'a ilişkin anlatılardan birine göre tanrıça Athena Asklepios'a Gorgon adlı yılansı varlığın kanını vermiştir. Efsaneye göre Gorgon'un sol tarafında bir canlıyı öldürecek kadar zehirli bir kanın, sağ tarafında ise bütün hastalıkları - hatta ölümü dahi - iyileştirecek bir şifanın bulunduğuna inanılırdı. Dolayısıyla şifa ile yılan arasında Asklepios öncesinde kurulan bir ilişki hâlihazırda söz konusuydu. Elbette yılan figürünün ssrarla mitik sembollerde yer almasının tek sebebi bu değildir. Kutsallığı yer altı, yer üstü ve gök olmak üzere üç ayrı mekânda değerlendiren kadim insan için her üç âlemle irtibatı bulunan bir varlığın kudretli, güçlü olarak anılması muhtemeldir. Bu sebeple yılan aynı zamanda gücü temsil etmektedir. Dahası mitik anlatılarda pek çok kez tanrısal varlıkların yılan şekline girdiği düşünüldüğünde, yılanın hayvan ve insan arasında bir geçiş formu olarak algılandığını ifade edebiliriz. ${ }^{38}$ Ayrıca sürekli gömlek değiştirmeleri onları ölümsüzlüğün sembolü yapmış durumdadır. Kısacası yılan hakkındaki tüm bu çağrışımlar, tababet ilmi ile ilişkilendirilmiş, dolayısıyla tıp tanrısı Asklepios'un sembolünün yılanlı bir asa olmasına sebep olmuş olmalıdır. Nitekim bu görsel hâlâ tıbbın sembolü olarak kullanılmaktadır. ${ }^{39}$

\section{Asklepios Kültü}

Asklepios kültü yaşayan bir kült değildir ancak günümüzde tıbbî olarak kullandığımız bazı önemli kavramların ve nesnelerin kökeni

babaları olsa da bunlardan hiçbiri meseleyi doktrine etmemiştir. Oysa Augustinus bu Pavlusçu yorumu geliştirerek asli günah şeklinde doktrine edilmesini sağlamıştır.

37 Jayne, The Healing Gods of Ancient Civilizations, s. 302.

${ }^{38}$ Harrison, Prolegomena to the Study of Greek Religion, s. 327.

${ }^{39}$ Harrison, Prolegomena to the Study of Greek Religion, s. 341. 
hala Asklepios ile ilişkilidir. Kayıtlara göre Asklepios beyaz bir chiton (elbise) giyiyor ve elinde yılanlı bir asa tutuyordu. Beyaz elbise doktorların beyaz önlügünü, yılanlı asa ise ecza ve tıbbın sembolü olan "kadüse" yi çağrıştırmaktadır. Asklepios'un kızları olan $H y$ gieia/hygiene; hijyen, Panakeia/panacea; bütün dertlerin şifası ve Meditrine/medicine; "ilaç" anlamlarında kullanılan günümüzdeki en önemli tıbbî kavramlardır. Bu çağrışımlar Asklepios'un önemini modern perspektiften ortaya koyar niteliktedir. Kültün yaygin olduğu zaman diliminde gündelik hayatta ne derece önemli olduğunu ortaya koymak için ise dönemin tababetle ilişkili kavramlarına göz atmak gerekecektir.

Kaynaklarda tababet ilminde uzmanlaşan kimselere asklepiad, yine asklepiadların eylemlerini icra ettikleri antik bir şifahane ve tapınak olarak tasarlanan mimari yapılara ise Asklepeion/asklepion adı verildiği anlaşılmaktadır. ${ }^{40}$ Sadece bu iki isimlendirme dahi Helen coğrafyasında Asklepios'un tıbbın kurucusu olarak betimlendiğini ortaya koymaya yeterlidir. Elbette ki, tababet ilmi ile ilişkili tek varlık Asklepios, tek kült de Asklepios kültü değildir. Asklepios haricinde Sentor Kheiron, Apollon ve Serapis de tıpla ilişkilendirilir. ${ }^{41} \mathrm{O}$ halde tababete bunca karaktere rağmen Asklepios'u öne çıkaran ve Yunan dünyasının pek çok bölgesinde yaygın bir külte sahip olmasina neden olan nedir?

Bize göre Asklepios'un olumlu şöhreti sadece tababet ilmine vakıf olmasından değil, bu ilmi insanlık lehine kullanmasından ve asklepiadlar aracılığıyla bu ilmin sürekliliğini sağlanmasından kaynaklanmaktadır. Nitekim asklepionların işlevlerinden birisi de budur. Bu tapınak-şifahane kompleksleri bir yandan hastalıkların tedavisine yönelik hizmet sunarken, diğer yandan tıp birikiminin insanlığa aktarılması amacını gütmektedir. Günümüz açısından seküler olarak görülebilecek bu işlev esasında kutsaldır. Asklepionlarda tıp hizmeti tanrısal yönlendirmelerle tayin edilen ritüeller aracılığıyla verilmektedir. ${ }^{42}$ Dolayısıyla tedavi sürecinin bir ritüel olduğunu söyleyebiliriz. Bu ritüeller asklepionlardaki rahip-hekim-

${ }^{40}$ Walter Burkert, Greek Religion, Harvard University Press, Massachussets:1985, s. 215.

${ }^{41}$ Pindarus, Nemeae, III, s. 54-56.

42 Jayne, The Healing Gods of Ancient Civilizations, ss. 276-277

168 
ler olan asklepiadlar aracılı̆̆ıyla gerçekleştirilirdi. Kısacası hem şifahane hem de tapınak hizmeti gören bu mimari yapılar Asklepios etrafında şekillenen kültün en bariz özelliği olmuştur denilebilir.

Kimi anlatılarda "kahraman" kimilerinde ise "tanr1" olarak nitelenen Asklepios'un onuruna pek çok Yunan şehrinde heykeller dikilmiş ve asklepionlar inşa edilmiştir. Zaman içerisinde Asklepios kültünün önem kazandığı ve Grek dünyasının vazgeçilmez tapımlarından biri olduğu gözlemlenmektedir. Adına ilk tapımın MÖ. VI. yüzyıl civarında Epidarius'ta ortaya çıktığı ve MÖ. IV. yüzyılda Asklepios'u simgeleyen öğelerin diğer şehirlerde inşa edilen tapınaklara taşınarak kültün bölge haricine yayıldığı aktarılır. ${ }^{43}$ Kültün Yunan şehirlerine taşınmasına ilişkin olarak kaynaklar Atina'daki vebayı sebep olarak göstermektedir. Neredeyse şehir halkının üçte birinin ölümüyle sonuçlanan vebanın giderilmesinde Atina panteonundaki tanrıların yetersiz kaldığının düşünülmesi, Epidarius'taki kültün Atina'ya taşınmasına neden olmuştur. Kısa süre içinde veba gerilemiş ve bu durum Asklepios'un başarısı olarak izah edilmiştir. Bu sebeple Asklepios adına Piraeus (Pire) ve Atina şehirlerinde tapınaklar inşa edilmiş ve Asklepios şehir panteonuna dâhil edilmiştir. ${ }^{4}$

Çoğunlukla elinde yılanlı bir asa ile betimlenen edilen Asklepios'un kopya heykellerinin Grek şehirlerine taşınmasına ilişkin pek çok benzer anlatıya ulaşmak mümkündür. Sikyon bölgesindeki tapınağa Asklepios heykelinin katırlar üzerinde getirildiği bilgisi kaynaklarda yer alırken, Atina'daki Asklepion kroniklerinde heykelin Epidarius'tan ilkel bir araba vasıtasıyla taşındığı bilgisine rastlanılmaktadır. ${ }^{45}$ Asklepios heykellerinin taşınması neticesinde Atina, Bergama ve Kos gibi şehirler zamanla kültün merkezi olan

\footnotetext{
43 Jane Harrison, Prolegomena to the Study of Greek Religion, Meridian Books, New York:1955, s. 344. Bazı kaynaklara göre Asklepios tapımı ilk olarak Trikka adı verilen Tesalya bölgesindeki antik bir yerleşim yerinde başlamış, daha sonra Epidarius'a gelmiştir. Epidarius'ta Asklepios kültünün ünlenmesi neticesinde kült sürekli olarak Epidarius ile ilişkilendirilmiştir. Strabo, Geography, II, Trans. H. C. Hamilton, Bohn's Classical Library, Londra:1856, s. 36; Jon D. Mikalson, Ancient Greek Religion, Blackwell, Malden, MA: 2005, s. 22.

${ }^{44}$ Mikalson, Ancient Greek Religion, s. 22.

${ }^{45}$ Burkert, Greek Religion, s. 214.
} 
Epidarius'tan daha önemli bir hale gelmiştir. Özellikle Bergama' daki asklepionun diğer bölgelerdekilere oranla daha çok ilgi gördüğü ifade edilir. Bugün İstanköy olarak bilinen antik Kos şehri de kült açısından önemli bir merkezdir. Ancak burayı önemli kılan sebep sadece asklepionun varlığı değil, tıp tarihi açısından çok önemli bir ismin burada yetiştiğinin düşünülmesidir. Bu kişi, Koslu asklepiad olarak da bilinen Hippocrates'tir. ${ }^{46}$ Hippocrates' in Asklepios'un torunlarından olduğu sanılmaktadır. Asklepiad olarak görev yapan kimselerin Asklepios'un oğulları olarak anılmasından ötürü Hippocrates'e atfedilen torunluk mertebesinin biyolojik olmadığını söylemek daha makuldür. Ancak Hippocrates'in yemin metninde Asklepios'un yer alması ikili arasındaki ilişkinin ehemmiyetini gözler önüne sermektedir. İlk olarak Hesiodos ve Pindarus'un anlatıları aracılığıyla tanrısal bir figüre dönüşen Asklepios, Hippocrates' in yemini aracılığıyla sürgit bir mitik kahraman olmanın yanı sıra günümüz açısından değerlendirildiğinde bilimsel bir kuruculuk rütbesi kazanmıştır. Hippocrates'in söz konusu metni yalnızca Asklepios'a değil başta tanrı Apollon'a ve Asklepios'un çocukları Hygieia ve Panakeia olmak üzere bütün tanrı ve tanrıçalara ant ile başlamaktadır:

Hekim Apollon, Asklepios, Higieia, Panakeia üzerine ve bütün Tanrı ve Tanrıçaların huzurunda yemin ederim ki, yeteneğim ve gücüm elverdiğince bu ant ve sözleri tutacağım. ${ }^{47}$

\section{Asklepionlar}

Antik Yunan tapınaklarında tapım ayinler, kurbanlar, dualar, ilahiler ve çeşitli törenler eşliğinde sürdürülmektedir. Bu nedenle tap1naklar bu ritüellere göre tasarlanmıştır. Ancak asklepionlar kendine özgü işlevlerinden ötürü farklı bir tasarıma sahiptir. Bu farklılık asklepionların sağlığı koruma ve hastalıkların tedavisi gibi işlevlerinden ötürü tapınak-şifahane şeklinde yapılandırılmasına sebep olmuştur. Bu gaye ile şehir dışında hijyenik mekanlarda, doğa ile iç

\footnotetext{
${ }^{46}$ Burkert, Greek Religion, s. 215.

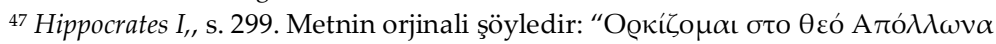

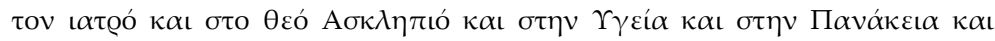

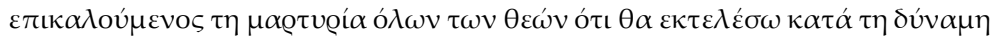

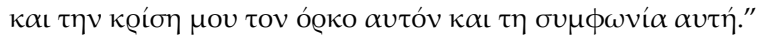


içe oluşturulan tapınaklar, ayrıca tedavi için gerekli ihtiyacı karşılayacak bir şekilde inşa edilmişlerdir. ${ }^{48}$ Bu yönüyle asklepionlar bir taraftan şifahane işlevi görmekte ve asklepiadların yetişmesine ve hastaların tedavi edilmesine aracılık etmekte, öte yandan Grek dini ritüllerini yerine getirmede önemli bir merkez vazifesi görmektedir. Bir diğer ifadeyle asklepionlar profan mekânlar değil aksine kutsal mekânlar olarak kabul edilmektedir. Nitekim Epidarius'taki asklepionun girişinde "Hoş rayihalı tapınağa giren saf olmalı. Saflıktan kasıt kutsal düşünceye sahip olmaktır" şeklindeki kitabe de bu kutsallığa işaret etmektedir. ${ }^{49}$ Tapınağın bu iki yüzü kültün Roma dönemindeki belirgin özelliklerindendir. Dahası M.S. II. yüzyılda Efes bölgesinde tıbbi bir yarışmanın tertip edilmesine ilişkin veriler tapınağın aynı zamanda bilimsel bir merkez olarak da kullanıldığına işaret etmektedir.

İlk asklepionun Strabo'nun iddiasına göre Trikka bölgesinde kurulduğuna ilişkin bir kayıt varsa da, yazarlar çoğunlukla kültün doğuşu için Epidarius'a işaret eder ve en görkemli asklepionun bu bölgede kurulduğunu kaydeder. Ayrıca Asklepios için düzenlenen festivale "Epiduria" isminin verilmesi, kült merkezinin Epidarius olduğu tezini desteklemektedir. ${ }^{50}$ Kaynaklar bu bölgede MÖ. VI. yüzyılda ilk asklepionun varlığına işaret etmekte ve M.S. 355 yılına dek varlığını koruduğunu kaydetmektedir. Günümüzde hâlâ devam eden arkeolojik kazılar Epidarius şehrinin asli halini ortaya çıkarmaya çalışmaktadır. Muhtemelen kazı çalışmaları neticesinde şehirdeki asklepiona dair daha detaylı ve elle tutulur bilgilere ulaşılacaktır. Ancak şu ana kadar edinilen bilgilere göre Epidarius'un yalnızca Asklepios tapımı için değil, diğer kültler için de önemli bir dini merkez olduğunu ortaya koymaktadır. Arkeolojik verilerin

\footnotetext{
${ }^{48}$ Hart, "Asclepius", s. 234; Edelstein-Edelstein, Asclepius: Collection..., s. 370. Plutarch asklepionların şehir dışında yapılmasına ilişkin (i) şehrin dışındaki doğa ile iç içe hayatın daha sağlıklı olduğuna inanılması, (ii) Asklepios kültünün doğduğu Epidarius'ta tapınağın şehir dışında olması ve (iii) tapınağın yerine tespit etmekle görevlendirilen yılanın şehir dışını seçmesi ihtimallerini zikreder. Plutarch, Moralia, Trans. by. Frank C. Babbitt, Harvard University Press, London:1962, s. 141.

${ }^{49}$ Porphyry, On Abstinence from Killing Animals, Trans. by. Gillian Clark, Bloomsbury, London:2000, s. 62.

${ }^{50}$ Jayne, The Healing Gods of Ancient Civilizations, s. 294.
} 
şehrin içinde 800 adet tapınak ortaya çıkarması bu iddiayı doğrulamaktadır.

Kültün Epidarius'tan sonra Bergama'ya ve Kos'a; daha sonra ise pek çok Yunan şehrine ulaştığ 1 söylenmektedir. ${ }^{51}$ Bu merkezlerin haricinde Roma döneminde Kartaca, Ege adaları, İtalya, İspanya, Mısır gibi bölgelere de şifa merkezleri kurulmuştur. Herhangi arkeolojik bir veri olmamasına karşın, kültün Romalı lejyonlar aracılığıla İngiltere'ye dahi ulaştığı nakledilir. ${ }^{52} \mathrm{Bu}$ asklepionlardan Bergamada'ki tapınağın kalıntıları asklepion yerleşkesine ait önemli ipuçları sunar. Şehir merkezinden oldukça uzak bir bölgeye ve genelde dağların eğimli bölgelerine inşa edilen asklepionların girişinde tünel tarzında bir yapı bulunmaktadır. Bu yapı bize hastaların hemen asklepiona kabul edilmediğini, öncelikle bir ön teşhisin konulduğunu göstermektedir. Her ne kadar Asklepios tapımının yayılması ile veba hastalığının ortadan kalkması arasında bir ilişki kurulsa da, kaynaklar asklepionlara vebalı hastaların alınmadığını aktarırlar. Nitekim ileride bahsedeceğimiz tedavi yöntemleri de bu şifahanelerde ölümcül hastalıklardan ziyade daha basit yaralanma, uzuv kırılmaları veya çıkıklarının tedavi edildiğini anlamamızı sağlamaktadır. Ayrıca arkeolojik kazılar neticesinde tapınak içinde veya çevresinde bulunan el ve ayak resim ve heykelleri de bu iddiayı doğrular niteliktedir. Bu da asklepionlara daha çok çiftçilerin ya da askerlerin gittiğini göstermektedir.

Elbette ki tedavi edilen hastalıklar bununla sınırlı değildir. Şehirden uzak kompleks bir yapı olarak tasarlanan ve adeta mini bir şehir görünümündeki asklepionlar burada uzun süreli hastaların kaldığını göstermektedir. Hidroterapi ve müzikoterapinin tedavi yöntemi olarak kullanılması akıllara hemen akıl hastalığını getirmektedir. Nitekim kaynaklar da yaygın olarak akıl hastalarının bu merkezlerde tedavi edildiğini doğrulamaktadır. Üstelik Hıristiyan-

\footnotetext{
${ }^{51}$ Edelstein-Edelstein, Asclepius: Collection..., s. 371; Hart, “Asclepius", s. 235.

52 Hart, "Asclepius", s. 235.
} 
lıkta günahkârlara verilen ilahi bir ceza olarak kabul gören akıl hastalığının, asklepionlarda tam anlamıyla tıbbi bir hastalık olarak değerlendirildiği nakledilmektedir. ${ }^{53}$

Bergama'daki tapınağı asklepion yapıları için model alacak olursak bu tapınak-şifahanelerde tapım ve tedavi sentezinin mimariye yansıması ile karşılaşırız. İki veya üç katlı olarak yapılan asklepionlarda tedavi amaçlı su kanalları yer alır. Tiyatro ve kütüphane gibi sosyal mekânlara da yer veren yapıda uyku odaları ile asklepiadların barınakları, çatı katında ise tapınak yer alır. ${ }^{54}$

Asklepios tapımının bir diğer önemli şehri Hippocrates'in de yetiştiği düşünülen Kos'tur. Buradaki asklepion eğimli bir arazi üzerine üç teraslı bir yapı olarak inşa edilmiştir. En alt bölümde tedavi amaçlı sunulan kükürtlü su kaynakları ve Roma döneminde inşa edilen hamam bulunmaktadır. Orta bölümde iki adet küçük tapınak ve bir sunak yer alır. Bu bölüm aynı zamanda asklepiadların ikamet ettikleri yerdir. En üst kısımda ise Asklepios kültüne ait Dorik bir tapınak bulunur. ${ }^{55}$

\section{Tedavi ve Ritüel}

Asklepionlarda medikal işlemler olarak hidroterapi, diyet, masaj, egzersiz ve uyku terapisi kullanıldığı ifade edilir. ${ }^{56}$ Ayrıca hastalıkların tedavisi için yılan ve köpek gibi hayvanlardan faydalanıldığ aktarılmaktadır..$^{57}$ Uyku esnasında Asklepios'un hastanın rüyasına girdiği ve ona bazı komutlar vererek tedavi ettiğine inanılır. Asklepios'un bilicilik yeteneği ile ünlü Apollon'un oğlu olduğu hatırlanırsa bu yeteneğin kimden tevarüs ettiği anlaşılabilir. ${ }^{58}$ Tedavi süreci uyku öncesinde sunulan bir kurban ve dua takdimeleri ile başlar ve tedavi sonunda Asklepios'a sunulan şükran takdimesi ile

\footnotetext{
53 Angelos Chaniotis, "Illness and Cures in the Greek Propitiatory Inscriptions and Dedications of Lydia and Phrygia", Ancient Medicine in its Socio-Cultural Context, Ed. by. Horstmanshoff, Ph.J. van der Eijk and P.H. Schrijvers, AmsterdamAtlanta:1995, vol. II, s. 327.

${ }^{54}$ Hüseyin Üreten, "Helenistik Dönem Pergamon Kenti Tanrı ve Kültleri”, Tarih Araştırmaları Dergisi, C. 22, S. 35, 2004, ss. 206-208; Osman Bayatli, Bergama Tarihinde Asklepion, Bergama Belediyesi Kültür Yayınları, 1993.

${ }^{55}$ Coldstream, "Greek Temples", ss. 91-92.

${ }^{56}$ Hart, "Asclepius", s. 234.

${ }^{57}$ Hart, "Asclepius", s. 234.

${ }^{58}$ Harrison, Prolegomena to the Study of Greek Religion, s. 342.
} 
nihayete erer. Dolayısıyla tedavi işleminin bütünüyle kutsal bir ritüel olduğu söylenebilir. ${ }^{59}$ Uyku terapisi haricinde hidroterapi, müzikoterapi, masaj, diyet ve egzersizler de asklepionlarda tedavi yöntemleri olarak kullanılmaktadır. ${ }^{60}$

Epidarius başta olmak üzere pek çok Grek şehrinde var olan bu kültün, aynı bölgelerdeki kadim kültlerle de ilişkisi bulunmaktadır. Nitekim Epidarius bölgesinde Miken uygarlı̆̆ından kalma Apollon Maleatas kültü de aynı zaman dilimi içinde yaşamaya devam etmiştir. Corinth'de ise Apollon kültü ile Asklepios kültünün birleştirildiği söylenmektedir. Asklepionlar, festival zamanlarında çok özel kültlerin gölgesinde kalsa da, özellikle günlük tapımların yoğunlaştığı bir merkez konumundadır. ${ }^{61}$

\section{Roma Döneminde Asklepios Kültü}

Grek topraklarında Roma hâkimiyetinin artması neticesinde Asklepios kültünün Roma dini içerisinde yer edindiği görülmektedir. Kültün MÖ. 292 yılında Roma dininin bir parçası olduğu düşünülmektedir. ${ }^{62}$ Şair Ovidius'un anlatımına göre Asklepios kültünün Roma'ya taşınması bölgedeki veba hastalığıyla ilişkilidir. Bütün medikal uğraşlara rağmen vebanın etkisinin bölgede artırmasından ötürü kehanet merkezi Delphi'ye bir elçi gönderilir. Delphi kâhini vebayı ortadan kaldıracak gücün Apollon'un oğlunda olduğunu söylemesi üzerine Asklepios heykeli Epidarius'tan deniz yolu ile Roma'ya getirilmiştir. Romalılar da tıpkı Yunanlar gibi kısa süre içinde Asklepios kültüne tapınmaya başlamıştır. ${ }^{63}$

Pek çok yazara göre Roma dini orijinal olmaktan öte çevre dini geleneklerin pratiklerinden oluşan senkretik bir yapıya haizdir. İmparatorluğun yükseliş çağında elde edilen topraklarda var olan dini uygulamalar ve kültler aynıyla veya değişerek Roma'ya taşınmıştır. Örneğin kökeni Pers geleneğine dayanan Mitra kültü ve aslı kadim Mısır topraklarında yer alan tanrıça İsis kültünün Roma'ya taşındığı

\footnotetext{
59 J.N. Coldstream, "Greek Temples: Why and Where?, Greek Religion and Society, Ed. P. E. Easterling, J. V. Muir, Cambridge University Press, Cambrdige:1985, s. 92; “Burkert, Greek Religion, s. 215.

6060 Jayne, The Healing Gods of Ancient Civilizations, ss. 278-285.

${ }^{61}$ Burkert, Greek Religion, s. 215.

${ }^{62}$ J. A. North, Roman Religion, Oxford University Press, Oxford:2000, s. 36.

${ }^{63}$ Ovid, The Metamorphoses, Bk. XV, ss. 443-447.
} 
bilinmektedir. Grek panteonundaki pek çok tanrısal varlı̆̆ın farklı isimlerle Roma'da kabul edildiği aşikârdır. Yine kökeni Mısır'a dayanan Osiris kültünün yeni bir versiyonu olan Serapis kültü üzerinden Romalı bir karaktere büründüğü görülmektedir. ${ }^{64}$ İlginç olan hikmet ve verimlilik tanrılarının senkretik bir yorumu olduğu düşünülen Serapis'in özelliklerinden birisi de hastalıkları iyileştirmesidir ki, bu özelliğin kaynağı Asklepios'tur. Daha da ilginci, Asklepios'un Romalılar tarafından tapımının sürdürüldüğü zaman diliminde Serapis adına inşa edilen Serapiumların var olması ve bu kültün Hıristiyanlığın yayıldığı zamana kadar devam etmesidir. Açıkçası bu durum Roma dininin senkretik yapısı ile izah edilebilir. Roma dininin Yahudilik ve Hıristiyanlık gibi hakikat iddiasından ziyade sosyal bir işleve sahip olduğunu söylemek yerinde olacaktır. Şüphesiz ki, dinlerin toplumu bir arada tutmak gibi bir işlevi her zaman söz konusu olmuştur. Ancak Roma geleneğinde bu işlevin ehemmiyetinin çok daha fazla olduğunu söylemek mümkündür.

\section{Şeytanlaştırma ve Kültün Sonu}

Epidarius'ta başlayıp önce Yunan sonra ise Roma topraklarına yayılan Asklepios kültünün özellikle MS. II. yüzyılda Roma dininin en önemli tapımlarından biri olarak kabul gördüğü ifade edilir. Aynı yüzyıl içerisinde Roma'da popülaritesi artan başka bir din daha vardır: Hıristiyanlık. İmparatorluğun pek çok baskı ve kovuşturmasına rağmen Hıristiyanlık gün geçtikçe müntesip sayısını artırmaktadır. Bu durum şüphesiz ki pagan Romalıları rahatsız etmiştir. Aynı şekilde pagan uygulamalar da Hiristiyan yazarlarca yerilmektedir. III. yüzyılın sonuna doğru Diocletianus döneminde (MS. 284-305) H1ristiyanlar Asklepios tapımına katılmaya zorlanmışlar, kült adına kurban sunmayanlar ise öldürülmüştür.65 Ancak IV. yüzyılın ilk çeyreğinde siyasi otoritenin yönü Hıristiyanlığa dönmüş ve paganHıristiyan çekişmesi Hıristiyanlık lehine daha da şiddetlenmiştir. Constantine ile Hıristiyanlar arasındaki yakınlaşma ilk zamanlar pagan Roma dini aleyhine yaptırımlar getirmediyse de ilerleyen zamanlarda durum IV. yüzyıl öncesine nazaran değişmiş hatta pagan

${ }^{64}$ Ken Dowden, Religion and The Romans, Bristol Classical Press, Londra:1995, ss. 66-67,74.

${ }^{65}$ Bkz. J. Maksimovic, "Early Christian Martyrs Who Refused to Worship the Cult of Asclepius in the Times of Diocletian", Acta Medico-Historica Adriatica, C. 8, S. 2, 2010, ss. 239-260. 
uygulamaların yasaklanması ve pagan tapınak ve kült merkezlerinin yıkılması söz konusu olmuştur. Constantine ile başlayan bu sürecin halefleri tarafından - Julian hariç - daha şiddetli bir şekilde devam ettirildiği görülmektedir. Dahası bir yüzyıl öncesinde Hıristiyanlar pagan tanrılara tapmaya zorlanırken bu kez pagan tanrılara kurban sunanlar için idam cezasının öngörüldüğü de kayıtlar arasindadır. ${ }^{66}$

Paganlar aleyhine uygulanan yaptırmmlar bununla da kalmamış, kimi pagan tapınakları kiliseye çevrilirken kimileri de yıkılmıştır. Eusebios'un aktardığına göre yıkılan tapınaklar arasında Kilikya asklepion da vardır. Yıkımın akabinde tapınakta herhangi bir tanrı ya da insanları iyileştiren bir ruhun bulunmadığını, insanların yıllarca gerçek olmayan bir varlığa inandıklarını da ifade eden yazar, tapınağın yerle bir edilmesiyle önceki çlgınlıktan herhangi bir iz kalmadığını da eklemektedir. ${ }^{67}$ Ancak Eusebios'un bu iddiası bazı kaynaklar tarafından reddedilmektedir. Aksine Kilikya' daki asklepionun Julian döneminde faal olduğunu aktaran kayitlar bulunmuştur. Pagan yazar Libanius ise Kilikya'daki tapınağın II. Constantius tarafından yıkıldığına yer vermektedir. ${ }^{68}$ Bir başka önemli asklepion olan Bergama'daki tapınak ise III. yüzyılın ortasında deprem neticesinde yıkılmıştır. Ancak yeniden inşa edilmemiştir. Diğer tapınakların akıbeti hakkında ise kesin bilgi yoktur. Bazılarının hastaneye dönüştürüldüğü, bazılarının ise Hıristiyanlarca ve doğal afetler sonucunda yıkıldığ 1 düşünülmektedir. ${ }^{69}$

Pagan tapınakların yıkılması ve bu nedenle pagan inancinın gerilemesi, Hıristiyanlığın hızla yayılması ve imparatorluk dini olarak kabul görmesinin bir sonucu olarak okunabilir. Ancak onca tapınak içerisinden, sadece tapım merkezi olmayıp dönemin

\footnotetext{
${ }^{66}$ Dowden, Religion and The Romans, ss. 88-90.

67 Eusebios, Life of Constantine, Trans. A. Cameron, S. Hall, Clarandon, Oxford:1999, s. 145.

68 Cameron-Hall, Eusebios, Life of Constantine, Clarandon, Oxford:1999, s. 304. Roma dönemindeki tapınağının ilk yıkımı değildir. Epictetus, İskender'in eşini bir hastalık nedeniyle kaybetmesi sonucunda Asklepios tapınağını yaktırdığını nakleder. Epictetus, Discourses, II, Trans. W. A. Oldfather, Harvard University Press, Londra:1956, s. 397.

${ }^{69}$ Hart, "Asclepius", s. 236.
} 
şifahanesi konumunda - gündelik hayat açısından önemli bir merkez - olan asklepionların maruz kaldığı akıbetin arka planını ortaya koymak gerekmektedir. Bu bağlamda erken dönem Hıristiyan ve pagan yazarların Asklepios için kullandığı ifadeleri karşılaştırmalı olarak tahlil etmek yerinde olacaktır.

Oratio isimli eserinde Aristides (ö. MS. 181), Asklepios için şu ifadelere yer verir: "O (Asklepios), evrenin rehberi ve yöneticisi, herkesin kurtarıcısı ve ölümlülerin koruyucusudur... O her şeyin babası ve yapıcısı/yaratıcısıdır...". ${ }^{70}$ Neo-Platonistlere göre ise Asklepios "evrenin kendisi aracilı̆̆ıla var olduğu ruh, onun dengede, sağlıklı ve genç kalmasını sağlayan, Zeus ve Apollon ile birlikte pagan teslisinin son uknumu ve evrenin varlığından önce var olan tanr1..."71 olarak görülür. Hıristiyanlığı reddetmesinden ötürü "dönme Julianus" olarak da anılan imparator II. Julianus, İsa ve Asklepios biyografilerinin benzerliğinin farkındadır. Hıristiyanlara Karşı" isimli eserinde "Asklepios (ilk) ziyaretini gökten yeryüzüne yaptı; ilk önce Epidarius'ta insan suretinde göründü... sonra Bergama'ya, İyonya'ya ve Tarentum'a oradan da Roma'ya. Sonra Kos'a ve Aigai'e geldi. Şu anda ise karada ve suda, her yerde... O hasta bedenleri iyileştirir ve günahkâr ruhları kaldırır"72 diye yazmıştır. Seçilen metinlerdeki ifadeler Asklepios'un sadece bedenleri iyileştiren bir şifacı olmadığını, ayrıca ruhları da kurtaran (soter), evreni yöneten, evrenden önce var olan (logos), tanrısal oğulluk mertebesine erişen bir varlık olarak algılandığını ortaya koymaktadır.

Pagan yazarların övgü dolu ifadeleri Hıristiyan yazarlarca "gerçek dışı, uydurma" olarak değerlendirilir. Tertullianus Asklepios'u dünya için tehlikeli bir canavar olarak görmektedir. ${ }^{73}$ Constantine'nin oğlu Crispus'un akıl hocası olan Lactantius ise (ö. MS. 320), Asklepios için "şeytan atası" ifadesini kullanmaktadır. ${ }^{74}$ Bir diğer yazar Eusebios ise Asklepios'un bir kurtarıcı ve şifacı olduğuna ve uyku yöntemiyle pek çok kimseyi iyileştirdiğine inanıldığını

\footnotetext{
70 Alexia Petsalis-Diomidis, Truly Beyond Borders: Aelius Aristides and the Cult of Asklepios, Oxford University Press, NewYork: 2010, ss. 200-201.

${ }^{71}$ Edelstein-Edelstein, Asclepius: Collection...,II, ss. 108.

72 Julian, Against to Galilaeans, Harvard University Press, Cambridge:1923, s. 375

73 Edelstein-Edelstein, Asclepius: Collection...,II, s. 132.

${ }^{74}$ Lactantius, Divine Institutes (II.16), Trans by. Anthony Bowen, Peter Garnsey, Liverpool University Press, Liverpool:2003, s. 163.
} 
kaydeder. Oysa Eusebios'a göre bu durum hakikat değil, aksine bir kandırmacadır. Asklepios tapımının ruhlara büyük zararlar verdiğini aktarır. Aynı zamanda insanların gerçek kurtarıcı ve şifacı olan İsa' yı anlamalarına da engel olmaktadır. ${ }^{75}$

Hıristiyan yazarlar metinlerinde açıkça ifade etmeselerde onları rahatsız eden şey İsa ve Asklepios arasındaki benzerliklerdir. Henüz erken dönemde Yuhanna'daki "şeytanın tahtı" ifadesinin muhatabı sonraki yüzyıllarda Hıristiyan misyonu açısından bir tehlike olarak kalmaya devam etmiş olmalıdır. Bu tehlikeyi bertaraf edebilmek için bir yandan apolejetik metinler devreye sokularak Asklepios şeytanlaştırılırken öte yandan da kült merkezleri tahrip edilmiştir. Yunan mitolojisi açısından ikincil bir statüye sahip bir mitik figürün Hıristiyan misyonu açısından önemli bir tehlike görülmesine sebep olacak benzerlikler kültün neden sona erdiğini anlamamızı sağlayacaktır.

Asklepios anlatıları ile İnciller kıyas edildiğinde görülecektir ki, pek çok yönden İsa ve Asklepios ortak özelliklere sahiptir. Öncelikle her ikisi de tanrısal bir figür olarak kabul görmüştür. Metinler her ikisine de varlık öncesi tanrılık payesi vermiş, her iki isim "logos" olarak değerlendirilmiştir. Bununla birlikte iki isim de biri insani diğeri tanrısal kökene haizdir. Doğum hikayeleri onların insani kökenine atıf yapar. Her iki karakterin anneleri tanrısal değil insani doğaya sahiptir. Ancak doğum hikâyelerindeki mucizevi haller onları sıradan insanlar olmaktan çıkarıp tanrısal doğalarına vurgu yapan anlatıları destekler. Asklepios şifacı ve kurtarıcı vasıfları gereği pek çok hastayı tedavi etmiş ve hatta ölüleri diriltmiştir. Neticesinde Zeus tarafından öldürülmüş ve yeniden dirilerek Grek panteonunda yerini almıştır. İsa Mesih'e gelince İncillerin aktardığı bilgilere göre, kötürümleri, topalları, cüzzamlıları ve âmâ kimseleri iyileştirmiştir. Kim bilir belki de İsa'nın kötürümleri iyileştirdiği ifade edilen Baytsayda havuzu Filistin bölgesinde yer alan asklepionlardan biridir.

İsa ile Asklepios arasındaki benzerlikler yukarıdakilerle sınırlı değildir. İsa tıpkı Asklepios gibi ölüleri diriltmiş, çarmıhta can vermiş ancak üç gün sonra dirilerek insanlığın yegâne kurtarıcısı olduğuna inanılmıştır. Dolayısıyla her iki figür de "soter" kimliğini

75 Eusebios, Life of Constantine, s. 303. 
taşımaktadır. Asklepios, Zeus ve Apollon ile birlikte, İsa ise Baba ve Kutsal Ruh ile birlikte teslisin uknumlarından biri olarak vasfedilmiş, tanrısal oğulluk mertebesinde tesliste yerlerini almışlardır. Şifa kabiliyeti Asklepios'tan sonra onun öğrencileri olan asklepiadlara geçerken benzeri bir durum İsa ve havarileri arasında görülmüştür.

Bu benzerlikler Hıristiyan yazarların pek çok Grek tanrısına rağmen neden 1srarla Asklepios üzerinde durdukları hakkında önemli veriler sunmaktadır. ${ }^{76}$ Bununla birlikte her iki tanrısal varlığın tamamıyla aynı olduğu da söylenemez. Her iki biyografide birtakım bariz farklar görülür ki, bu nedenle olsa gerek Hıristiyan yazarlar asıl kurtarıcının İsa olduğunu, Asklepios ve benzeri şifacı kültlerin bir kandırmacadan ibaret olduğunu öne sürmüştür. Dolayısıyla sahte bir şifacı ve kurtarıcı olarak değerlendirilen Asklepios kültü Hıristiyanlığın İsa imajına zarar vermektedir. Bu sebeple kültün ortadan kalkması için bir hayli çaba gösterilmiştir.

\section{Sonuç}

Aklepios'a ilişkin anlatıların belirgin iki aşaması söz konusudur. Bunlardan ilki tanrılaştırmadır ki, "anthropos" bir kahramandan antropomorfik bir tanrı figürüne evrilme metinler aracılığıyla kolaylıkla takip edilebilmektedir. Tanrısallık ile birlikte etrafında şekillenen kült özellikle MÖ. VI. yüzyılda kült merkezi Epidarius'tan Grek coğrafyasına yayılmış, aynı topraklarda Roma hâkimiyetinin gerçekleşmesi sonucunda ise Romalılar tarafından devam ettirilmiştir. Külte ait tapınaklar diğer Greko-Romen tapınaklarından farklı olarak aynı zamanda bir şifahane olarak tasarlanmıştır. Asklepios heykellerinin taşınması ve asklepionların farklı Yunan şehirlerinde inşa edilmesiyle birlikte kült Greko-Romen kültürün önemli bir parçası olmuştur. Tanrısal akrabalık bağı, mucizevi doğumu, ölüleri diriltmesi ve ölümden dirilmesi gibi efsanevi anlatılar zamanla Asklepios'un Yunan ve Roma dinlerinde "soter" karakterli tanrisal bir varlık olarak kabul görmesine neden olmuştur. Ancak bu kurtarıcılık fikri Hıristiyan yazarları rahatsız etmiştir ki, böylece şeytanlaştırma evresi başlamıştır. Hıristiyanlarca evrensel kurtuluş doktrininin yalnızca İsa'ya has kılınmasından ötürü apolejetik metinler vasitasıyla onun "şeytan ve sahte kurtarıcı" olduğu ifade edilmiştir. Apolojetik saldırıları Constantine döneminde paganlar

76 Edelstein-Edelstein, Asclepius: Collection...,II, ss. 255. 
aleyhine başlatılan yaptırımlar izlemiştir. Kilikya sınırları içinde kalan asklepion tahrip edilmiş, Julianus döneminde yeniden inşa edilmek istenmişse de bu gerçekleştirilememiştir.

Özetle Asklepios tapımının hâlihazırda Apollon tapımının önemli bir merkezi olan Epidarius' ta başlaması ve bu tapımın yerine ikame edilmesi ile başlayan şöhreti, veba salgını karşısındaki çaresizlik nedeniyle geniş bir coğrafyaya yayılmış ve kendisinden önceki kültleri devre dışı bırakmıştır. Ancak Roma'daki dini rengin Hıristiyanlık lehine değişmesiyle birlikte Asklepios tapımı da selefi olan kültlerle aynı kaderi paylaşarak ortadan kaybolmuş yerine İsa imajı ikame edilmiştir.

\section{Kaynakça}

Agelidis, Soi "Cult and Landscape at Pergamon", Sacred Landscapes in Anatoliaand Neighboring Regions, Ed. by. C. Gates, J. Morin, T. Zimmermann, British Archeological Report, Oxford:2009.

Ancient Greek Lyrics, Trans by. Willis Barnstone, Indiana University Press, Indianapolis: 2010.

Antoninus, Marcus Aurelius, Meditations, Trans. M. Hammond, Penguin Books, Londra:2006.

Apollodorus, The Library II, Harvard Univeristy Press, New York.

Bayatlı, Osman, Bergama Tarihinde Asklepion, Bergama Belediyesi Kültür Yayınları, 1993.

Burkert, Walter, Greek Religion, Harvard University Press, Massachussets: 1985.

Cameron, A., - Hall, s., Eusebios, Life of Constantine, Clarandon, Oxford: 1999.

Chaniotis, Angelos "Illness and Cures in the Greek Propitiatory Inscriptions and Dedications of Lydia and Phrygia", Ancient Medicine in its SocioCultural Context, Ed. by. Horstmanshoff, Ph.J. van der Eijk and P.H. Schrijvers, Amsterdam-Atlanta:1995, vol. II.

Cicero, De Legibus, II, 8,19, De Natura Deorum, III.

Coldstream, J.N., “Greek Temples: Why and Where?, Greek Religion and Society, Ed. P. E. Easterling, J. V. Muir, Cambridge University Press, Cambrdige:1985.

Cosmopoulos, Michael, Greek Mysteries, Routledge, New York:2005.

Dowden, Ken, Religion and The Romans, Bristol Classical Press, Londra:1995,

Edelstein, Emma J., Edelstein, Ludwig, Asclepius: Collection and Interpretation of the Testimonies, John Hopkins University Press, Londra: 1998. 
Epictetus, Discourses, II, Trans. W. A. Oldfather, Harvard University Press, Londra: 1956,

Eusebios, Life of Constantine, Trans. A. Cameron, S. Hall, Clarandon, Oxford: 1999,

Graves, Robert, The Greek Myths, I, The Folio Society, London: 1998

Grimal, Pierre, Mitoloji Sözlü̈̆ü: Yunan ve Roma, Kabalcı, İstanbul:2012

Gül, Ahmet, “Lokman Hekim ve Ögütleri”, Erciyes Üniversitesi İlahiyat Fakültesi Dergisi, S. 2, Kayseri:1985.

Harman, Ömer Faruk, "Lokman”, Diyanet İslam Ansiklopedisi, TDV, Ankara:2003, c. 23.

Harrison, Jane, Prolegomena to the Study of Greek Religion, Meridian Books, New York:1955.

Hart, Gerald, "Asclepius: God of Medicine" Canadian Medical Association Journal, 1965: V. 92.

Hesiod, Homeric Hymns and Homerica, Ed. By. G. P. Gooldi Tr. Hugh G. Evelyn White, Harvard University Press, London:1982

Hippocrates I: Ancient Medicine, Trans. W. H. S. Jones, Cambridge University Press, Londra: 1957.

Homer, Iliad, Trans by. A.T. Murray, Harvard University Press, Londra:2001.

Jayne, Walter A. The Healing Gods of Ancient Civilizations, University Books, New York: 1962.

Julian, Against to Galilaeans, Harvard University Press, Cambridge:1923.

Lactantius, Divine Institutes (II.16), Trans by. Anthony Bowen, Peter Garnsey, Liverpool University Press, Liverpool:2003.

Lurie, Samuel; Glazerman, Marek, "The History of Ceserean Technique", American Journal of Obstetrics and Gynecology, 2004, c.189, v. 6

Maksimovic, J., "Early Christian Martyrs Who Refused to Worship the Cult of Asclepius in the Times of Diocletian", Acta Medico-Historica Adriatica, C. 8, S. 2, 2010.

Matyszak, Philip, The Greek and Roman Myths, Thames \& Hudson, New York: 2010.

McCants, William F., Kültür Mitleri, Çev. Merve Tabur, İthaki, İstanbul: 2012 Mikalson, Jon D., Ancient Greek Religion, Blackwell, Malden, MA: 2005.

North, J. A., Roman Religion, Oxford University Press, Oxford:2000.

Ovid, The Metamorphoses, Bk. II, Trans. Horace Gregory, The Viking Press, New York: 1958.

Panagiotidoi, Olympia, “Asclepius' Myths and Healing Narratives: Counter-Intuitive Concepts and Cultural Expectations", Open Library of Humanities, c. 2, s. 1, 2016 (DOI: http://dx.doi.org/10.16995/olh.34).

Petsalis-Diomidis, Alexia, Truly Beyond Borders: Aelius Aristides and the Cult of Asklepios, Oxford University Press, NewYork: 2010. 
Pindar, Olympian Odes, Pythian Odes, Ed. and Trans. William H. Race, Harvard University Press, Londra:1997.

Plutarch, Moralia, Trans. by. Frank C. Babbitt, Harvard University Press, London:1962.

Porphyry, On Abstinence from Killing Animals, Trans. by. Gillian Clark, Bloomsbury, London:2000

Strabo, Geography, II, Trans. H. C. Hamilton, Bohn's Classical Library, Londra:1856.

Üreten, Hüseyin, "Helenistik Dönem Pergamon Kenti Tanrı ve Kültleri”, Tarih Araştırmaları Dergisi, C. 22, S. 35, 2004. 